\title{
Feasibility Study of Composting Technology in Local Government Case Study: Sub-district Municipality, Suratthani Province
}

\author{
Chutimon Somboonmark and Taweep Chaisomphob
}

\begin{abstract}
This study was focused on the municipal solid waste management of rural community by investigate the waste generation rate and evaluates the MSW produced from Thachi sub-district municipality, Surat thani Province in order to study the feasibility for use the composting technology "Serial-Self Turning reactors (STRs)" by characterize the putrescible waste that are useful for composting.

Municipal solid waste (MSW) consists of a high proportion of biodegradable materials especially food waste contained large reserved of nutrients. The composting technology is the option for processing the enormous quantities of biodegradable solid waste, can reduce the volume of wastes placed in landfills, source separated waste should be improved. Municipal solid waste by public participation was undertaken in term of community-based solid waste management system (CBM) based on source separation practice as recycling waste, biodegradable waste for use as a material for composting. This research studies with the composite materials between kitchen waste with bulking agent collected from agricultural sector such as dried leave, yard waste, empty palm fruit bunch (EFB) and cow manure by experimental scale composting.
\end{abstract}

Index Terms-Municipal solid waste management (MSW), organic waste, composting, serial-self turning reactor (STR).

\section{INTRODUCTION}

Municipal solid waste management become crisis, especially in Local administrative organization, sub-district municipality, MSW were unsuitably disposed by open burning and open dumping resulting in accumulate of solid waste, release toxic substance and creating unsanitary condition can effect to human health and environment. As for the local administrative organization did not provide appropriate waste management system, they lack of long-term master planning and no cooperative planning on MSW management [1]

According to Municipal solid waste stream in Asian Countries is composed of high fraction of organic materials more than $50 \%$ with high moisture content [2]. MSW consists of biodegradable materials, which were decomposed during dispose to landfill causing gas release and leachate [3].

Manuscript received April 30, 2016; revised August 27, 2016.

Chutimon.Somboonmark is with Sirindhorn International Institute of Technology, Thammasat University, 99 Moo 18, Km. 41 on Paholyothin Highway Khlong Luang, Pathum Thani 12120, Thailand (e-mail: chutimon.mook@gmail.com).

Taweep.Chaisomphob Was with Sirindhorn International Institute of Technology, Thammasat University. He is now with the Department of Civil Engineering. Thailand (e-mail: taweep@ siit.tu.ac.th).
Tachi sub-district municipality (Tambon) have many MSW management problems such as the budget of Local government is not sufficiently allocated for MSW management system, lack of materials and technology for coping with this issues and improper MSW management practice has been found.

Therefore this paper aims to study the current situation of MSW management system and community-based MSW management project. Include study on the potential for apply organic waste composting technology, MSW quantity and composition, MSW characterization and experimental study of co-composting was undertaken.

\section{A. Study Area}

Thachi sub-district municipality, Bannasarn district, Surat thani province, Located at the south of Thailand far from muang surat thani 65 kilometers. There are 6 villages. Thachi has total area $77.80 \mathrm{~km}^{2}$. Land occupation intensity is much by agricultural part; Rubber, Oil palm, seasonal fruit cultivation and farming. The most of population is farmer. There are 1,426 households in Thachi sub-district municipality, the total population was including 4,931 [4].

\section{MATERIALS AND METHODS}

\section{A. Investigation and Evaluation of MSW Management System}

Data collecting was performed by interviews, household survey, field observation and questionnaire. This study explore the:

1) Quantity and typed of municipal solid waste in Thachi sub-district municipality by waste sampling

2) Questionnaires survey the knowledge and strategies of municipal solid waste management with sub-district municipality authorities

3) Study the current situation of municipal solid waste by interview and collect the secondary data on municipal solid waste management

\section{B. Cooperative Planning and Operating Process of Municipal Solid Waste Management by Public Participation}

The community-based MSW management project leads by trained social innovator and leadership of villages with education on $3 \mathrm{Rs}$ project, include waste separation at source by following activities,

- Field observation, interview

- Group discussion 
- Workshop of community-based MSW management planning

C. Study on Potential to Use Serial-Self Turning Reactors Composting Technology

\section{1) Waste Sampling and composite characterization}

The samples were collect from truck before transport to disposal site then spread flat on a clean plastic sheet and waste were manually sorted into 10 components; Food waste, Leaves, Papers, Metals, Textiles, Plastics, Glasses, Leather, Hazardous materials and miscellaneous materials. Each component was weighed and recorded. $1 \mathrm{~kg}$ of composite samples was collected in polyethylene bags and transported to laboratory test, moisture content was analyzed immediately.

TABLE I: MIXING MATERIAL PROPERTIES

\begin{tabular}{l|rrrr}
\hline \multicolumn{1}{c|}{ Parameter } & $\begin{array}{c}\text { C/N } \\
\text { ratio }\end{array}$ & $\begin{array}{c}\text { Moisture } \\
\text { Content } \\
{[\%]}\end{array}$ & $\begin{array}{c}\text { Total } \\
\text { Nitrogen } \\
{[\%]}\end{array}$ & $\begin{array}{c}\text { Total Organic } \\
\text { Carbon } \\
{[\%]}\end{array}$ \\
\hline Food waste & 22.35 & $75 \%$ & $2.071 \%$ & $46.29 \%$ \\
Vegetable scraps & 21.15 & $60 \%$ & $1.862 \%$ & $39.28 \%$ \\
Empty palm fruit & 37.33 & $33.33 \%$ & $1.352 \%$ & $50.47 \%$ \\
bunch (EFB) & 13.5 & $15.80 \%$ & $0.882 \%$ & $11.91 \%$ \\
Leaf compost & 14.2 & $30.07 \%$ & $1.49 \%$ & $21.30 \%$ \\
Cow manure & 13.7 & $20.12 \%$ & $0.724 \%$ & $9.92 \%$ \\
Agricultural waste & & & & \\
\hline
\end{tabular}

\section{2) Chemical characterization of $M S W$}

The waste samples were collected into the zip lock plastic bag. Mixed waste for each day of sampling was delivered to the laboratory for chemical analysis.

The determination of percentage of moisture content, ash content, volatile solid content and calculate percentage of fixed carbon according to ASTM standards D5231-5292,

a) Moisture content (drying at $105^{\circ} \mathrm{C}$ )

The percent moisture of the MSW samples was determined by weighing of samples before and after drying in an oven at $105^{\circ} \mathrm{C}$ to a constant weight. The percent moisture content (\%) was calculated as a percentage loss in weight before and after drying.

$$
\% \text { Moisture }=\frac{[\text { Wetweight }- \text { Drywight }]}{\text { Wetweight }} \times 100 \%
$$

\section{b) Volatile solid}

A volatile solid is the amount of matter that volatilizes when heated. A volatile solid is a useful approximation of the amount of organic matter present in sample. The volatile solid content is determined by the method of ignition of the sample at $550 \pm 50^{\circ} \mathrm{C}$. After combustion, the samples are weighed to determine the ash dry weight, with volatile solids being the difference between the dried solids and the ash.

$$
\% \text { Volatile }=\frac{\left[W_{D}-W_{A s h}\right]}{W_{D}} \times 100 \%
$$

c) Ash content (combustible residue left after ignition volatile solid)

$$
\% \text { Ash }=100-\% \text { Volatile }
$$

Ultimate analysis includes determination of \% content in Nitrogen (N), which was also used to define the proper MSW to achieve suitable $\mathrm{C} / \mathrm{N}$ ratios for biological conversion processes. Total nitrogen was determined by Kjeldahl nitrogen digester and calculation.

$$
\% \text { Nitrogen }=\frac{\left[V_{\text {Sample }}-V_{\text {Blank }}\right] \times \text { conc.ofH }_{2} \mathrm{SO}_{4}(\mathrm{~N}) \times 1.4007}{\text { weight }_{\text {Sample }}(g)}
$$

\section{Experimental Study of Organic Waste Composting}

\section{1) Composting materials}

Food waste was collected from restaurants; vegetable waste was taken from groceries store in community and local market in neighboring district. Cow manure was taken from farming. Leaf compost, yard waste, agricultural waste and empty palm fruit bunch (EFB) was used as a bulking agent, can take from agricultural sectors in community. Properties of raw materials show in Table I.

\section{2) Experimental Set up}

The experimental study was used small reactors with dimension $0.45 \times 0.45 \times 0.45 \mathrm{~m}^{3}$ with $10 \mathrm{~cm}$. thickness of foam cover. The volume was designed to equal to one fourth of the serial-self turning reactor (STR). The aeration was supplied by air compressors through the air flow rate and the PVC pipe with aeration rate is $0.5 \mathrm{litre} / \mathrm{min} / \mathrm{kg} \mathrm{OM}$. Composting factor are controlled by measurement of parameter can affect to the compost condition. The temperature was measured by thermocouple and data logger. Pile turning on day 7, 14 and 21 after compost. After 28 days, chemical properties of final product, sent to the Central Laboratory for testing.

\begin{tabular}{|c|c|c|c|c|}
\hline \multirow{7}{*}{$\begin{array}{c}\text { Mixing } \\
\text { ratio }\end{array}$} & \multicolumn{4}{|c|}{ Materials proportion } \\
\hline & Experiment I & Experiment II & Experiment III & Experiment IV \\
\hline & $\mathrm{F}^{(\mathrm{a})}: \mathrm{V}^{(\mathrm{b})}: \mathrm{EFB}$ & $\mathrm{F}^{(\mathrm{a})}: \mathrm{V}^{(\mathrm{b})}: \mathrm{EFB}: \mathrm{LC}^{(\mathrm{c})}$ & $\mathrm{CM}^{(\mathrm{d})}: \mathrm{F}+\mathrm{V}: \mathrm{AW}^{(\mathrm{e})}$ & $\mathrm{OC}^{(\mathrm{f})}: \mathrm{CM}: \mathrm{EFB}$ \\
\hline & $0.5: 0: 0.5$ & 1: $0: 0.5: 0.5$ & $1: 0.25: 0$ & $1: 0.5: 0.25$ \\
\hline & $0.5: 0.25: 0.5$ & $1: 0.25: 0.5: 0.5$ & $1: 0.25: 0.25$ & $0.5: 0.25: 0.25$ \\
\hline & $0.5: 0.5: 0.5$ & $1: 0.5: 0.5: 0.5$ & $1: 0.25: 0.5$ & $1: 0.25: 0.25$ \\
\hline & $0.5: 0.75: 0.5$ & $\begin{array}{c}1: 0.75: 0.5: 0.5 \\
00.5\end{array}$ & $1: 0.25: 0.75$ & $0.5: 0: 0.25$ \\
\hline
\end{tabular}

To find the best compost materials, different mixing ratio was required. Four composting experiments of different materials were studied, shown in Table II.

${ }^{\text {(a) }}=$ Food waste $\quad{ }^{\text {(c) }}=$ Leave compost $\quad{ }^{\text {(e) }}=$ Agricultural and yard waste ${ }^{(\mathrm{b})}=$ Vegetable waste $^{(\mathrm{d})}=$ Cow manure $\quad{ }^{(\mathrm{f})}=$ Organic commingled waste

Mixing ratio of co-composting depend on $\mathrm{C}$ : $\mathrm{N}$ ratios and moisture content of material. Bulking agent were added for maintain the composting condition [9].

\section{RESULT}


A. Current Situation of Solid Waste Management in Study Area; Thachi Sub-district Municipality

\section{1) Municipal solid waste management problems}

Thachi sub-district municipality, lacking on data of MSW quantity and composition, did not have appropriate technology based waste management, no specific basis of strategies on MSW management. Improper disposal, open dumping and open burning and high cost for waste disposal (11.63 \$ per ton). Household source separation is not commonly practices, people did not place waste bag at collection points and illegal solid waste disposal resulting in environmental contaminated.

\section{2) Waste generation rate}

On average, waste generation rate in Thachi sub-district municipality is $0.647 \mathrm{~kg} /$ capita/day.

\section{3) Municipal solid waste characterization}

In this study, MSW characterization based on source of waste as rural community was analyzed in term of material types, see fig.1. According to a study on waste composition and characterization, monthly waste sampling from Nov 2015 to April 2016 (six months), Average result of MSW compose a large number of biodegradable waste $(53.78 \%)$.

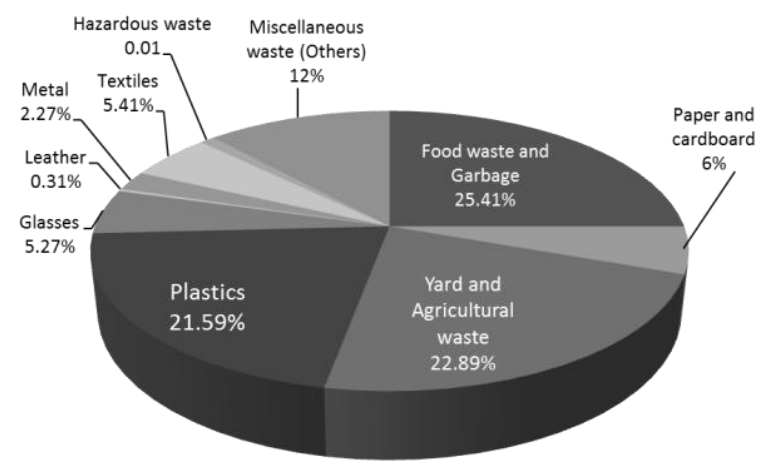

Fig. 1. MSW composition.

For proximate analysis of MSW shows in Table III, percent moisture of combined MSW is 50.28, composting technology by used municipal organic waste as a raw materials for composting can be done.

TABLE III: RESULT OF CHEMICAL ANALYSIS OF MSW

\begin{tabular}{|l|c|}
\hline \multicolumn{1}{|c|}{ Parameter } & Average Result \\
\hline Moisture (\%) & 50.278 \\
\hline Total Solid (\%) & 59.76 \\
\hline Volatile Solid (\%) & 87.06 \\
\hline \% Carbon & 48.37 \\
\hline \% Ash & 12.94 \\
\hline Total Nitrogem & 0.135 \\
\hline
\end{tabular}

\section{4) Solid waste management practices}

\section{a) Waste reduction and separation}

MSW were load manually by waste collection crews, one driver and three waste collection crews who load MSW from bin to the waste collecting truck and sorted the recyclable waste; plastic bottle, glass bottle, can, cardboard and etc. However, household source separation is not commonly practiced in this community.

b) Waste collection

MSW collection, transportation and disposal in Thachi sub-district municipality is the responsibility by sub-district municipality, waste were not separated (mixed waste) before collecting. Local authorities provide one waste collecting truck and 500 cylindrical plastic bins (200 liters) for household, and waste discarded in the municipal bins is collected by the municipal waste collection crew.

c) Waste transfer

Waste collection service of Thachi Sub-district Municipality covering area of 6 villages. Waste was collected from door to door of household by rear loaded compact collection truck collects waste from the different collecting routes, waste were collected on Monday and Tuesday for 1,3,4 village and for 2, 5, 6 village, collect waste on Thursday and Friday. MSW collecting time, start from 09.00 a.m. to 12.00 p.m. and from 13.00 to 15.30 p.m., two trips per day. Collected MSW transported to neighboring disposal facilities.

\section{d) Waste treatment and disposal}

Waste was transported directly to disposal site in neighboring district, under contracting of Lucky Green Energy Company limited which produce and transport electricity from solid waste by incineration technology. Transporting and unloading distant is 50.6 Kilometers.

\section{B. Community Based Initiative}

Application for improve the MSW management system in Thachi sub-district municipality has not been appropriated technologies for implement with MSW management system. However, municipal authorities and households have willingness to solve the MSW management problem related to community-based MSW management project by public participation presented in the following activities,

- Notice board has been placed on public area used to be illegal dumped site, provide for all 6 village of sub-district municipality. It can make the people more realize with MSW problems; public spaces are not proper dumped site that encourage community conserving the environment.

- Recycling project has been done with primary schools to set up recycling waste banks to create environmental awareness among the children toward their future and can help their hometown reduce waste generated.

- Community-based MSW management project joined forced with the local stakeholders as the social innovator, to encourage household waste separation and recycling. They Organized a training courses on MSW separation at source and composting technologies for Thachi sub-district municipality, lead the people realize the potential of MSW management problem and value of the recyclable waste by sell to recycled junk shop and use biodegradable waste as materials for composting. However, many households stopped operating the waste recycle activity when did not continuous monitoring. Opposite with waste collectors have more potential for selling recyclable waste.

\section{Result of Experimental Study}

According to maturity of composting process was determined by examining of physical, chemical and biological characterization of final product. Final compost of experimental II and III was completed, formed in brownish 
black and soil-like. Maximum temperatures were achieved within 2-5 days of starting the ranged between $45-60^{\circ} \mathrm{C}$, can reach the thermophilic stage, then temperature decreased in each case. (See Fig. 2-3).

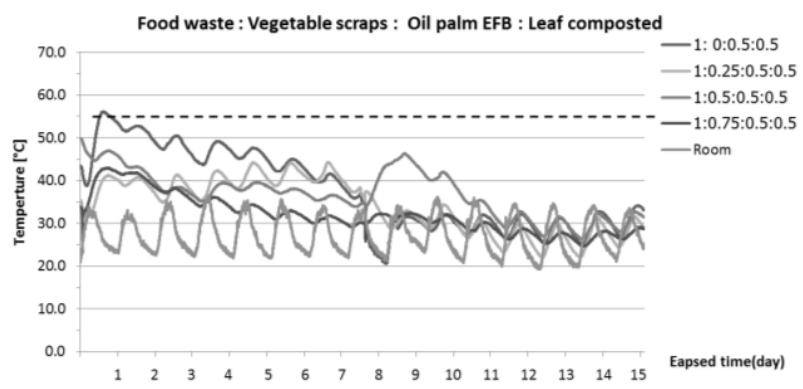

Fig. 2. Temperature profile of small-scale composting (experimental II)

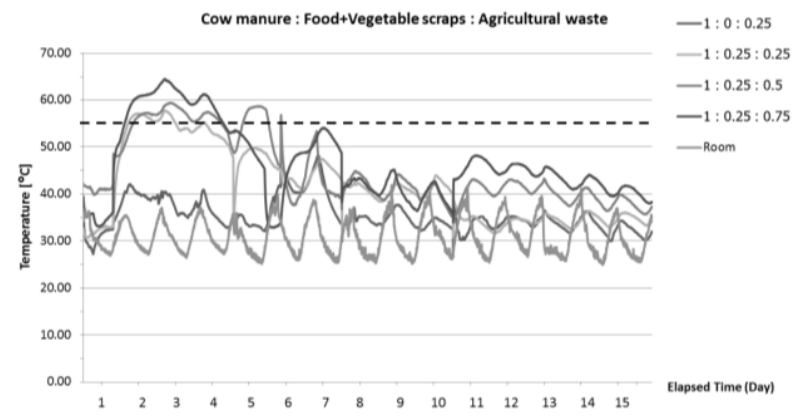

Fig. 3. Temperature profile of small-scale composting (experimental III).

Based on the standards for the conventional organic fertilizers determined by Land Developing Department (LDD) of Thailand provided on TABLE IV, the final product should contain nitrogen not less than $1 \%$, phosphorus not less than $0.5 \%$, and potassium not less than $0.5 \%$ [10]. Three cases of well compost mixed from this experiment obtained from cow manure, kitchen waste (Food +vegetable) mixed with agricultural and yard waste performed in TABLE II, contained 1.2-1.9 \% N, 0.9-1.6\% P, 3.4-4.1\% K. All parameters of final products in the six cases of compost mixed have clearly met the corresponding standards described on Table IV. Therefore, these final products can be used as soil nourishment and/or for plant nutrient source.

\begin{tabular}{|c|c|c|c|c|c|c|c|}
\hline \multirow{2}{*}{ Parameter } & \multirow{2}{*}{$\begin{array}{c}\text { DOA } \\
\text { Standard }\end{array}$} & \multicolumn{3}{|c|}{$\begin{array}{c}\text { Experimental II } \\
\mathrm{F}^{(\mathrm{a})}: \mathrm{V}^{(\mathrm{b})}: \mathrm{EFB}^{(\mathrm{f})}: \mathrm{LC}^{(\mathrm{c})}\end{array}$} & \multicolumn{3}{|c|}{$\begin{array}{c}\text { Experimental III } \\
\mathrm{CM}^{(\mathrm{d})}: \mathrm{F}+\mathrm{V}: \mathrm{AW}^{(\mathrm{e})}\end{array}$} \\
\hline & & 1: 0:0.5:0.5 & $1: 0.25: 0.5: 0.5$ & $1: 0.75: 0.5: 0.5$ & $1: 0.25: 0.25$ & $1: 0.25: 0.5$ & $1: 0.25: \mathbf{0 . 7 5}$ \\
\hline $\mathrm{pH}$ & $5.5-10$ & 8.34 & 7.43 & 7.73 & 6.37 & 6.11 & 7.69 \\
\hline $\begin{array}{l}\text { Electrical } \\
\text { Conductivity } \\
\text { (EC) }\end{array}$ & $\begin{array}{c}\leq 10 \\
\text { and/or } \\
\leq 15\end{array}$ & 21.10 & 22.14 & 23.69 & 20.73 & 42.52 & 38.13 \\
\hline $\begin{array}{l}\text { Moisture } \\
\text { Content }\end{array}$ & $\leq 30$ & 37.21 & 33.08 & 29.44 & 28.11 & 19.46 & 25.32 \\
\hline $\begin{array}{l}\text { Total } \\
\text { Nitrogen }\end{array}$ & $\geq 1$ & 2.58 & 2.58 & 2.21 & 2.56 & 1.85 & 1.91 \\
\hline $\mathrm{C} / \mathrm{N}$ & $\leq 20: 1$ & 21.58 & 19.19 & 17.08 & 16.31 & 11.29 & 14.69 \\
\hline $\begin{array}{l}\text { Total } \\
\text { Organic } \\
\text { Carbon } \\
\text { (TOC) }\end{array}$ & N/A & 1.34 & 1.34 & 1.45 & 1.53 & 1.27 & 1.51 \\
\hline $\begin{array}{l}\text { Organic } \\
\text { Matter }\end{array}$ & $\begin{array}{l}\geq 20 \\
\text { and/or } \\
\geq 30\end{array}$ & 1.59 & 1.46 & 1.52 & 1.66 & 1.17 & 1.26 \\
\hline $\begin{array}{l}\text { Total } \\
\text { Phosphate }\end{array}$ & $\geq 0.5$ & 8.29 & 8.15 & 8.11 & 8.09 & 8.27 & 8.18 \\
\hline $\begin{array}{l}\text { Total } \\
\text { Potassium }\end{array}$ & $\geq 0.5$ & 1.10 & 1.27 & 1.31 & 1.45 & 2.05 & 2.34 \\
\hline
\end{tabular}

\section{DISCUSSION AND RECOMMENDATION}

For strengthening up public responsibility of community-based MSW management for improve the system,

1) Provide refused bins for organic waste to household.

2) Reduce the amount of MSW by using leftover food as a material for composting facility. Include agricultural waste such as fruit peel, dried leave and palm residue.

3) Provide site central refuse collection point

4) Provide resource (material) and technology for waste collection and segregation such as the collection facility for recyclable waste and organic waste.

5) Support fund for MSW management campaigns

6) Provide resource for environmental and public health education including the technicians for inspects the communities to carry out their MSW.

7) Promote local market and groceries and agricultural sector in community separate biodegradable waste such as food waste, fruit peel and agricultural waste.

8) Household could be proactive in the MSW management project through: segregate waste at source.

\section{CONCLUSION}

Composting of municipal organic waste are feasible in this study, thus the final products of small scale composting can approach the standard properties of organic fertilizer determined by Land Development Department (LDD) of Thailand. Composting Technology can be used as a proper management for utilized the organic waste generated in community. Waste recycling campaign followed by community-based waste management projects, can reduce waste generation rate at the beginning of recycle project was provided, but lack of long term activities, some household had been stopped separating recyclable waste to sell for junk shop, because economic incentives are not significant. The leadership and community members of Thachi sub-district municipality should stimulate public cooperation in separation of recyclables waste and organic waste used for composting facilities by specified in community policy to strengthening and promotes environmental conservation and sustainable MSW management system.

\section{ACKNOWLEDGMENT}

I would like to thank you in research supported by the Advanced and Sustainable Environmental Engineering of TAIST-Tokyo Tech program, and Department of Common and Graduate Studies, Sirindhorn International Institute of Technology (SIIT), Thammasat University.

Many thanks to all correspondents and interviewees for the cooperation and valuable time, especially the mayor, official and staff of Thachi sub-district municipality sharing data, collecting waste samples and using building for experimental study. Include, neighboring district, local market of Bansong sub-district municipality providing the vegetable waste as us required. The authors would like to thank the Faculty of science, Suratthani Rajabhat University permit us for using their laboratory, really grateful to Laboratory of faculty of Public Health, Thammasat University for their Lab assistances train us to use Kjeldahl digester for total nitrogen 
analysis

\section{REFERENCES}

[1] PCD. (2015). Thailand Environmental Regulations. [Online] Available: www.pcd.go.th/info_serv/en_reg_polwaste.html

[2] ARRPET. (2004). "Municipal solid waste management in Asia," Thailand Asian Institute of Technology.

[3] Institute for Global Environmental Strategies (IGES). A guide for sustainable urban organic waste management in Thailand: Combining food, energy, and climate co-benefits. [Online]. Available: http://www.iges.or.jp

[4] Department of Provincial Administration (DOPA). Statistic information services: Population rate in 2015. [Online]. Available: http://stat.bora.dopa.go.th/stat/xstat/new/POPHSE/stat_t58.txt

[5] ASTM, "Standard test method for determination of the composition of unprocessed municipal solid waste," American Society for Testing and Materials, 1988.

[6] A. E. Greenberg et al., "Standard methods for the examination of water and wastewater," Washington, DC., American Public Health Association.

[7] R. Barrena et al., "Co-composting of hair waste from the tanning industry with de-inking and municipal wastewater sludges," Biodegradation, vol. 18, no. 3, pp. 257-268, 2007.

[8] Determination of Kjeldahl Nitrogen in soil, biowaste and sewage sludge. (2005). Expression of results. [Online]. Available: https://www.ecn.nl/docs/society/horizontal/STD6161_Kj-N.pdf
[9] United States Department of Agriculture: USDA. (2000). Part 637 Environmental Engineering National Engineering Handbook. [Online]. Available

on:http://www.nrcs.usda.gov/Internet/FSE_DOCUMENTS/nrcs143_0 22229.pdf

[10] Land Development Department (LDD). Corresponding standard of organic fertilizer. [Online]. Available: http://www.ldd.go.th/ldd/Fertilizer/Organic_Fertilizer.pdf

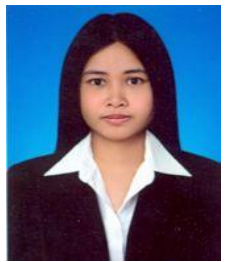

Chutimon Somboonmark was born on July 19, 1991, in Yala, Thailand. She graduated high school from Triam Udom Suksa School of the South. She received her bachelor's degree in bachelor of science (public health), major of environmental health and safety from Thammasat University, Pathumthani in 2014. Now, She is studying the master of engineering (engineering technology) TAIST Program (Thailand Advanced Institute of Science and Technology) major in advanced and sustainable environmental engineering (EnvE), under the cooperation of National Science and Technology Development Agency (NSTDA), Tokyo Institute of Technology (Japan) and Sirindhorn International Institute of Technology (SIIT).

Ms. Chutimon Somboonmark (master degree's student) and Assoc. Prof. Dr. Taweep Chaisomphop is her advisor about these study, He is the advisor of Civil Engineering Department at Sirindhorn International Institute of Technology. 